\title{
Biosecurity risks from stink bugs to New Zealand kiwifruit identified in Chinese language literature
}

\author{
David A.J. Teulon ${ }^{1,2, *}$ and Bingqin $\mathrm{Xu}^{1}$ \\ ${ }^{1}$ The New Zealand Institute for Plant \& Food Research Limited, Private Bag 4704, Christchurch, \\ 8140, New Zealand \\ ${ }^{2}$ Better Border Biosecurity (B3), New Zealand (B3nz.org) \\ ${ }^{*}$ Corresponding author: David.Teulon@plantandfood.co.nz
}

\begin{abstract}
Brown marmorated stink bug (BMSB), native to Asia including China, is a major invasive horticultural and crop pest in North America and Europe, and now threatens the southern hemisphere. BMSB has not established in New Zealand although it is regularly intercepted at its borders. Relatively little is known about the impact of BMSB on kiwifruit, an important horticultural crop in New Zealand; at least in English language literature. Searches were conducted in the Chinese National Knowledge Infrastructure (CNKI) platform using Chinese characters for BMSB (茶翅蝽) and kiwifruit (猕猴桃), and also in English, in international platforms. We identified 17 and eight publications, respectively, indicating that BMSB and yellow spotted stinkbug (YSSB) (麻皮蝽 and 黄斑蝽) are major pests of kiwifruit in China. Little information on BMSB or YSSB and their pest status in kiwifruit was found in English language searches in international platforms. Searching Chinese databases with Chinese characters in combination with searches in international databases is necessary to ensure comprehensive coverage for biosecurity risk assessment.
\end{abstract}

Keywords brown marmorated stink bug, yellow spotted stink bug, Halyomorpha halys, Erthesina fullo, biosecurity risk assessment, Actinidia, kiwifruit, China.

\section{INTRODUCTION}

This study examines two interlinking issues: (1) the potential impact of the brown marmorated stink bug (and other stink bugs) to the New Zealand kiwifruit industry; and (2) accessing information on pests and diseases from Chinese language literature.

The brown marmorated stink bug (BMSB) (Halyomorpha halys Stål) (Hemiptera: Pentatomidae) is an invasive alien species originating from East Asia that is now established in North America and Europe (Leskey \& Nielsen 2018), recently found in Chile (Faúndez \& Rider 2017), and threatening to establish in Australia and New Zealand (Haye et al. 2015). It is a serious pest of many agricultural and horticultural crops, as well as a significant nuisance pest, throughout its distribution and a significant biosecurity risk to New Zealand's plant systems (Anon. 2017a). Although the potential impact of BMSB on a range of New Zealand plant crops has been understood for some time (Duthie 2012), its potential impact on kiwifruit crops has not. The New Zealand BMSB risk analysis by Duthie (2012) did not mention kiwifruit and a major English language review of BMSB from Asian literature (Lee et al. 2013) listed only two references to kiwifruit and then in the context of kiwifruit being a host of BMSB and not necessarily as a pest. Kiwifruit was not mentioned in other recent major BMSB reviews (Rice et al. 2014; Leskey \& Nielsen 2018). The pest risk status of BMSB was rated as unknown on the StopBMSB website (Anon 2015). In 2018, knowledge of BMSB habitation of kiwifruit orchards in the stink bug's native and invaded ranges was still considered anecdotal 
(Lara et al. 2018).

Kiwifruit is one of New Zealand's most valuable horticultural crops, accounting for over $\$ 1.6$ B in exports in 2016 (Freshfacts 2017), and is potentially at risk from a range of invasive alien pests and pathogens not currently found in New Zealand. The risk of invasive alien species to New Zealand kiwifruit was clearly illustrated by the 2010 outbreak of Psa (Pseudomonas syringae pv actinidiae) (Vanneste 2017).

The two most commercially important kiwifruit species worldwide (including New Zealand), Actinidia chinensis and A. deliciosa, are native to China (Huang \& Ferguson 2001). It therefore follows that China is also a likely source of kiwifruit pests such as BMSB. Very little is published in English on the pests and diseases of kiwifruit in China and hence little is known about these potentially invasive species and their potential biosecurity risk to New Zealand. China is one of New Zealand's largest trading partners (Statistics New Zealand 2017) and an increasing source of tourists (Tourism New Zealand 2018) so that the biosecurity risk from China may be increasing.

Knowledge of plant pests and diseases by government and industry biosecurity specialists is important for the development of appropriate pre-border, at-border and postborder biosecurity activities to prevent their entry or minimise their impact in New Zealand. Historically, much of the information on invasive species has been relatively easily sourced from their native or introduced regions where information has been published in English. This is not the case for China. Previously, the authors have demonstrated the importance of searching biosecurity-related information in Chinese databases and in the Chinese language for a range of pests and pathogens found in China that are of biosecurity interest to New Zealand (Xu et al. 2016).

This current study builds on preliminary work reported by Teulon and $\mathrm{Xu}$ (2017) to explore the pest status of BMSB on kiwifruit in China, and compare strategies for obtaining this information in English and Chinese language, and international and Chinese search platforms.

\section{METHODS}

\section{Literature searches}

A range of literature searches using Latin and Chinese characters to identify publications regarding BMSB on kiwifruit in China were undertaken in several search platforms including: (1) Chinese National Knowledge Infrastructure (CNKI) using the 'subject' field, which examines the title, abstract and keywords of publications and the 'full text' field, which examines the title, abstract, keywords and full text of publications; (2) Web of Science (WoS; Thomson Reuters Ltd; USA) 'topic', which examines the title, abstract and keywords of publications for a selection of individual databases; (3) ProQuest Central (ProQuest, USA) using the 'anywhere' option, which examines the title, abstract, keywords and full text of publications in the database; and (4) Google Scholar, which examines words anywhere in articles, theses, books and abstracts. Scopus is not available to Plant and Food Research researchers. Search keywords, subjects or topics and search options are listed in Table 1. Searches included at least one form (English, Chinese, or Latin) each of BMSB and kiwifruit to identify publications containing both terms. The titles and abstracts of all papers (except those that could not be accessed, such as theses) were reviewed to ensure BMSB and kiwifruit were mentioned in the same document and that this was in the context of the pest status of BMSB on kiwifruit (as opposed to kiwifruit being a host plant).

The CNKI literature database was selected for the search since it was found to be the best Chinese database for providing biosecurity-related information in China in a previous study (Xu et al. 2016). The following terms were used in Chinese character searches of CNKI and Google Scholar: '茶翅蝽' (the Chinese common name for BMSB), and '猕猴桃' (the Chinese common name for kiwifruit) (Table 1). The Chinese characters for BMSB were determined by an initial search for the scientific name (Halyomorpha halys) in $\mathrm{CNKI}$ and then by matching them to appropriate 
Table 1 Literature searches for the brown marmorated stink bug and kiwifruit in China.

\begin{tabular}{|c|c|c|c|}
\hline $\begin{array}{l}\text { Platform } \\
\text { or Index }\end{array}$ & $\begin{array}{l}\text { Databases (and } \\
\text { extent of } \\
\text { coverage) }\end{array}$ & $\begin{array}{l}\text { Search 'subject', } \\
\text { 'keyword' or 'topic' } \\
\text { (some combination of) }\end{array}$ & Search options \\
\hline$\overline{\mathrm{CNKI}}$ & $\begin{array}{l}\text { China Academic } \\
\text { Journal Network } \\
\text { Publishing } \\
\text { Database }(1951->)\end{array}$ & $\begin{array}{l}\text { 'Halyomorpha halys', 'brown } \\
\text { marmorated stink bug,' } \\
\text { 'Actinidia', 'kiwifruit', } \\
\text { '猕猴桃', '茶翅蝽, }\end{array}$ & $\begin{array}{l}\text { 'subject' field } \\
\text { 'full text' field } \\
\text { 'precise' search }\end{array}$ \\
\hline WoS & $\begin{array}{l}\text { CAB (1973->), } \\
\text { WoS Core }(1900->) \text {, } \\
\text { KCI }(1980->), \\
\text { Russian Science } \\
(2005->)\end{array}$ & $\begin{array}{l}\text { 'Halyomorpha halys', 'brown } \\
\text { marmorated stink bug*', } \\
\text { 'BMSB', 'China*', 'Chinese*', } \\
\text { 'kiwif*', 'actinid'*' }\end{array}$ & 'topic' \\
\hline ProQuest & $\begin{array}{l}\text { Agricultural \& } \\
\text { Environmental } \\
\text { Science Database } \\
(1960->)\end{array}$ & $\begin{array}{l}\text { 'Halyomorpha halys', 'brown } \\
\text { marmorated stink bug*', } \\
\text { 'BMSB', 'China*', 'Chinese*', } \\
\text { 'kiwif*', 'actinid'”' }\end{array}$ & 'anywhere' \\
\hline Google Scholar & $\begin{array}{l}\text { WWW including: } \\
\text { academic publishers, } \\
\text { professional societies, } \\
\text { online repositories, } \\
\text { universities and } \\
\text { other web sites }\end{array}$ & $\begin{array}{l}\text { 'China', 'Chinese', 'Actinidia', } \\
\text { 'kiwifruit,' 'Halyomorpha halys', } \\
\text { 'brown marmorated stink bug', } \\
\text { 'BMSB', ‘猕猴桃', '茶翅蝽' }\end{array}$ & 'advanced search' \\
\hline
\end{tabular}

$\mathrm{CNKI}=$ Chinese National Knowledge Infrastructure; WoS = Web of Science.

Chinese characters within a publication where both Latin and Chinese names were used together. This was repeated three to four times to ensure an accurate translation had been achieved. The appropriateness of this approach was confirmed by the linked combination of 茶 翅蝽 and Halyomorpha halys in our subsequent searches (see Table 2). According to Sun (2017), '奇异果' is the Chinese common name for kiwifruit imported to China from New Zealand whereas '猕猴桃' is the Chinese common name for kiwifruit produced in China. Therefore “猕猴 桃' was used in the current study.

Searches in CNKI were carried out in April 2017 and those in WoS, ProQuest Central and Google Scholar conducted in March 2018. The number of articles for BMSB on kiwifruit in China published prior to April 2017 was obtained for equitable comparison between search platforms.

\section{Translations}

Relevant Chinese manuscripts were translated into English by one of the authors who is a native Chinese speaker with a biosecurity background. For BMSB, the appropriate Chinese common name had been determined prior to the searches (see above). A number of Chinese language publications also included reference to the yellow spotted stink bug (YSSB) (Erthesina fullo Thunberg), for which there appear to be two Chinese common names (麻皮蝽 and 黄斑蝽) (Table 2). However, no searches were conducted specifically for the YSSB with any characters (English, Chinese or Latin) in any of the search platforms. 
Table 2 Information on the pest status of pentatomid bugs on kiwifruit. Note all but two publications are in Chinese.

\begin{tabular}{|c|c|c|c|}
\hline $\begin{array}{l}\text { Species/family/ } \\
\text { English common } \\
\text { name }\end{array}$ & $\begin{array}{l}\text { Chinese } \\
\text { name }\end{array}$ & $\begin{array}{l}\text { Pest status (translated from Chinese for all } \\
\text { but two publications) }\end{array}$ & Reference \\
\hline \multirow{17}{*}{$\begin{array}{l}\text { Halyomorpha halys } \\
\text { brown marmorated } \\
\text { stink bug }\end{array}$} & 茶翅蝽 & 'significant damage to kiwifruit' ${ }^{1}$ & Song et al. $1997^{2}$ \\
\hline & 茶翅蝽 & ' + ' (in a damage scale up to +++$)^{1}$ & Song et al. $1998^{2}$ \\
\hline & 茶翅蝽 & 'one of the major pests of kiwifruit' & Zhang et al. 2000 \\
\hline & 茶翅蝽 & $\begin{array}{l}\text { 'serious damage' ... 'one of the major pest } \\
\text { species' }\end{array}$ & Guo \& Shi 2003 \\
\hline & 茶翅蝽 & 'major pest of kiwifruit' & Feng 2007 \\
\hline & 茶翅蝽 & $\begin{array}{l}\text { 'one of the most significant fruit pests' \& } \\
\text { 'affected ... and kiwifruit the most' }\end{array}$ & Li et al. $2007^{2}$ \\
\hline & 茶翅蝽 & $\begin{array}{l}\text { 'among various crops ... kiwifruit suffered } \\
\text { most from this pest' }\end{array}$ & Cai et al. 2008 \\
\hline & 茶翅蝽 & 'major pests of kiwifruit' & Zhao \& Qu 2008 \\
\hline & In English & 'attacks many plants including ... kiwifruit' & Yang et al. 2009 \\
\hline & 茶翅蝽 & $\begin{array}{l}\text { 'pest' and 'dominant species in kiwifruit } \\
\text { orchards' }\end{array}$ & Du et al. $2011^{2}$ \\
\hline & 茶翅蝽 & 'major pests of kiwifruit' & Ge 2012 \\
\hline & 茶翅蝽 & 'major kiwifruit pest' & Zhang et al. 2013 \\
\hline & 茶翅蝽 & 'major stinkbug attacking kiwifruit' & Yang et al. $2014^{2}$ \\
\hline & 茶翅蝽 & $\begin{array}{l}\text { 'stink bugs ... serious/severe damage/most } \\
\text { important pest' } 1\end{array}$ & $\begin{array}{l}\text { Zhang et al. } \\
2014^{2,3}\end{array}$ \\
\hline & 茶翅蝽 & 'one of the must controlled pests of kiwifruit' & Cui et al. $2017^{2}$ \\
\hline & 茶翅蝽 & 'major kiwifruit pest' & Gao \& Yang 2017 \\
\hline & In English & 'plagued by occasional outbreak' & Mi et al. 2017 \\
\hline \multirow{8}{*}{$\begin{array}{l}\text { Erthesina fullo } \\
\text { yellow spotted stink } \\
\text { bug }\end{array}$} & 麻皮蝽 & 'major pest of kiwifruit' & Feng 2007 \\
\hline & 麻皮蝽 & 'major pests of kiwifruit' & Zhao \& Qu 2008 \\
\hline & 麻皮蝽 & 'major pests of kiwifruit' & Ge 2012 \\
\hline & 麻皮蝽 & 'major kiwifruit pest' & Zhang et al. 2013 \\
\hline & 麻皮蝽 & 'major stinkbug attacking kiwifruit' & Yang et al. $2014^{2}$ \\
\hline & 黄斑蝽 & $\begin{array}{l}\text { 'stink bugs ... serious/severe damage/most } \\
\text { important pest' }\end{array}$ & $\begin{array}{l}\text { Zhang et al. } \\
2014^{2,3}\end{array}$ \\
\hline & 麻皮蝽 & 'one of the must controlled pests of kiwifruit' & Cui et al. $2017^{2}$ \\
\hline & 麻皮蝽 & 'major kiwifruit pest' & Gao \& Yang 2017 \\
\hline $\begin{array}{l}\text { Dolycoris baccarum } \\
\text { sloe bug }\end{array}$ & 斑须蝽 & $\begin{array}{l}\text { 'pest' and 'dominant species in kiwifruit } \\
\text { orchards' }\end{array}$ & Du et al. $2011^{2}$ \\
\hline Stinkbugs & 蝽 & 'major pest attacking kiwifruit' & Mi et al. 2007 \\
\hline
\end{tabular}




\section{RESULTS}

\section{Literature search comparisons}

Seventeen and eight publications identifying BMSB and YSSB, respectively, as pests of kiwifruit in China spanning 20 years (19972017) were found by literature searches in both international and Chinese databases (Tables 2 \& 3). All references to YSSB were in publications mentioning BMSB. One other publication was generic for stinkbugs. Of these 18 publications, only two were in English. Of the 16 Chinese language publications, six had abstracts in English and eight used Latin scientific names. Seven were completely in Chinese. Most were found using Chinese characters (14 out of 18) and 16 were found in CNKI (Tables $2 \& 3$ ). No relevant publications were found in English language searches of WoS and ProQuest, and only two were found in English language searches of Google Scholar, and one Mi et al. (2017) was published after April 2017 (Table 3). Four publications were found in Google Scholar when searching with Chinese characters but these were all found in CNKI. Publications found from all sources had additional citations to pests and diseases of kiwifruit in China, (including BMSB and YSSB) but these additional publications were not reviewed in this current study.

\section{Species identified in the literature searches}

Cui et al. (2017) indicated that there are least nine harmful stink bug species attacking crops and trees in China. These include: Aelia nasuta Wagner; Dolycoris baccarum (L); YSSB; Eurydema dominulus (Scopoli); Eurydema gebleri Kolenati; BMSB; Stollia guttiger (Thunberg); Tropidothorax elegans (Distant); and Acanthocis scaber (L). None of these are reported from New Zealand (MacFarlane et al. 2010). Both BMSB and YSSB were commonly listed as major kiwifruit pests (see above). Additionally, D. baccarum, along with BMSB, was reported as a pest and dominant species in kiwifruit orchards (Du et al. 2011).

The smaller number of publications on YSSB may reflect the study approach of searching only for BMSB, or that YSSB is of secondary importance compared with BMSB. It is noteworthy that not all translated articles considered BMSB to be a major pest (e.g. Song et al. 1998).

\section{Impact from stink bugs in Chinese kiwifruit}

Additional information gleaned from the translated publications that may help inform New Zealand's pre-border, at-border and postborder biosecurity system is discussed below.

There has been rapid development of the kiwifruit industry in China since the 1990s (Ferguson 2015), especially in the Shaanxi province. This expansion has led to serious pest and disease issues (Song et al. 1997; Guo \& Shi 2003) that limit further development of the kiwifruit industry (Song et al. 1998; Zhang et al. 2013, 2014). The disease Psa (Pseudomonas syringae pv. actinidiae) and stink bugs have become the most important crop-protection issues in kiwifruit orchards located in the vicinity of Xi'an, the capital city in the Shaanxi province (Zhang et al. 2014). The translated publications also provided lists and information on a wide range of other key pests and diseases of kiwifruit in China, as well as physiological disorders, which will be reviewed at a later date. In general, damage to kiwifruit from pests and diseases was lower within the natural geographic distribution of cultivated Actinidia, compared with newly cultivated regions (Song et al. 1998; Guo \& Shi 2003).

The majority of publications referred to BMSB in Shaanxi province, the major province for kiwifruit production in China (Ferguson 2015). In this province $\mathrm{BMSB}$ occurs in all regions where kiwifruit is cultivated (Song et al. 1997, 1998; Zhang et al. 2000; Guo \& Shi et al. 2003; Feng 2007; Li et al. 2007; Mi et al. 2007; Zhao \& Qu 2008; Du et al. 2011; Zhang et al. 2013, 2014; Mi et al. 2017). One publication mentioned BMSB and YSSB in kiwifruit grown in the vicinity of Shanghai (Ge 2012), and another reported their presence in kiwifruit grown in Hubei (Yang et al. 2014). Publications mentioning YSSB were mostly reports from Shaanxi province (Feng 2007; Zhao \& Qu 2008, Zhang et al. 2013, 2014). The life cycle of BMSB involves one generation per growing season in Shaanxi (Zhang et al. 2000; 
Table 3 Number of publications on brown marmorated stink bug and kiwifruit in China found in searches of CNKI, WoS, ProQuest and Google Scholar.

\begin{tabular}{|c|c|c|c|c|}
\hline Search platform & $\begin{array}{l}\text { Search characters that resulted } \\
\text { in relevant publication }\end{array}$ & $\begin{array}{l}\text { Relevant } \\
\text { publications }\end{array}$ & $\begin{array}{l}\text { Scientific } \\
\text { name }\end{array}$ & $\begin{array}{l}\text { English } \\
\text { abstract }\end{array}$ \\
\hline $\begin{array}{l}\text { CNKI 'subject' } \\
=\text { title, abstract, } \\
\text { keywords }\end{array}$ & $\begin{array}{l}\text { 猕猴桃 \& 茶翅蝽 } \\
\text { 狝猴桃 \& 茶翅蝽 } \\
\text { 猕猴桃 \& 茶翅蝽 }\end{array}$ & $\begin{array}{l}\text { Zhang et al. } 2000 \\
\text { Guo \& Shi } 2003 \\
\text { Feng } 2007\end{array}$ & $\begin{array}{l}\text { No } \\
\text { No } \\
\text { No }\end{array}$ & $\begin{array}{l}\text { No } \\
\text { No } \\
\text { No }\end{array}$ \\
\hline $\begin{array}{l}\text { CNKI 'full text' = } \\
\text { title, abstract, } \\
\text { keywords, } \\
\text { full text }\end{array}$ & $\begin{array}{l}\text { 猕猴桃 \& 茶翅蝽 } \\
\text { 猕猴桃 \& 茶翅蝽 } \\
\text { 猕猴桃 \& 茶翅蝽, brown } \\
\text { marmorated stink bug \& } \\
\text { kiwifruit, Halyomorpha halys } \\
\text { \& kiwifruit } \\
\text { 猕猴桃 \& 茶翅蝽 } \\
\text { Halyomorpha halys \& kiwifruit } \\
\text { 猕猴桃 \& 茶翅蝽 } \\
\text { Halyomorpha halys \& kiwifruit } \\
\text { 猕猴桃 \& 茶翅蝽 } \\
\text { 猕猴桃 \& 茶翅蝽, } \\
\text { Halyomorpha halys \& kiwifruit } \\
\text { 猕猴桃 \& 茶翅蝽 } \\
\text { 猕猴桃 \& 茶翅蝽 } \\
\text { 猕猴桃 \& 茶翅蝽, } \\
\text { Halyomorpha halys \& kiwifruit } \\
\text { 猕猴桃 \& 茶翅蝽 }\end{array}$ & $\begin{array}{l}\text { Mi et al. } 2007 \\
\text { Cai et al. } 2008 \\
\text { Zhao \& Qu } 2008 \\
\text { Du et al. } 2011 \\
\text { Ge } 2012 \\
\text { Yang et al. } 2014 \\
\text { Zhang et al. } 2013 \\
\text { Zhang et al. } 2014 \\
\text { Cui et al. } 2017 \\
\text { Gao \& Yang } 2017\end{array}$ & $\begin{array}{l}\text { No } \\
\text { Yes } \\
\text { No } \\
\text { Yes } \\
\text { No } \\
\text { Yes } \\
\\
\text { No } \\
\text { Yes } \\
\text { Yes }\end{array}$ & $\begin{array}{l}\text { Yes } \\
\text { Yes } \\
\text { No } \\
\text { Yes } \\
\text { No } \\
\text { No }\end{array}$ \\
\hline $\begin{array}{l}\text { WoS 'topic' = } \\
\text { title, abstract, } \\
\text { keywords }\end{array}$ & NA & None relevant & & \\
\hline $\begin{array}{l}\text { ProQuest } \\
\text { 'anywhere' = } \\
\text { title, abstract, } \\
\text { keywords, } \\
\text { full text }\end{array}$ & NA & None relevant & & \\
\hline $\begin{array}{l}\text { Google Scholar } \\
\text { (English) } \\
\text { 'anywhere in the } \\
\text { article' }\end{array}$ & $\begin{array}{l}\text { All words: China, Actinidia } \\
\text { At least one of the words: } \\
\text { 'Halyomorpha halys', 'Brown } \\
\text { marmorated stink bug', 'BMSB' }\end{array}$ & $\begin{array}{l}\text { Yang et al. } 2009 \\
\text { Mi et al. } 2017\end{array}$ & $\begin{array}{l}\text { In English } \\
\text { In English }\end{array}$ & \\
\hline $\begin{array}{l}\text { Google Scholar } \\
\text { (Chinese) }\end{array}$ & 猕猴桃 \& 茶翅蝽 & $\begin{array}{l}\text { Zhang et al. } 2000 \\
\text { Feng } 2007 \\
\text { Li et al. } 2007 \\
\text { Cui et al. } 2017\end{array}$ & $\begin{array}{l}\text { No } \\
\text { No } \\
\text { Yes } \\
\text { Yes }\end{array}$ & $\begin{array}{l}\text { No } \\
\text { No } \\
\text { Yes } \\
\text { Yes }\end{array}$ \\
\hline
\end{tabular}

CNKI = Chinese National Knowledge Infrastructure; WoS = Web of Science.

Lee et al. (2013) only indicates that Actinidia spp. are a host of BMSB. It does not indicate that BMSB is a pest of Actinidia spp. This publication was identified in the Google Scholar search in English. 
Guo \& Shi 2003) whereas YSSB has two (Feng 2007).

Both adults and nymphs of BMSB cause damage to kiwifruit by sucking sap from leaves or juice from fruit, resulting in leaf yellowing and black/blue spots/scars on the fruit (Song et al. 1997; Zhang et al 2000; Guo \& Shi 2003). Flower-, bud- or fruit-drop may occur and the injured part of the fruit becomes white and spongy, and eventually rots (Zhang et al. 2000; Guo \& Shi 2003; Feng 2007), thereby affecting fruit quality and storage (Feng 2007). Zhang et al. (2014) reported that stink bugs and other fruit feeding insects, caused more than $20 \%$ of fruit rot during kiwifruit storage.

Significant BMSB activity and damage to kiwifruit occurred between July and August/ September (Song et al. 1997; Zhang et al. 2000; Guo \& Shi 2003) or during the fruit growth period (Gao \& Yang 2017). In some districts, BMSB infestation levels were reported to be around $7-10 \%$ and up to $25-30 \%$ in seriously infected orchards (Zhang et al. 2000). Li et al. (2007) noted that smaller vines help in BMSB control, and Zhang et al. (2014) noted that BMSB was more apparent in older vines. Timing of YSSB infestations in Shaanxi is different from BMSB due its two generations; damage starts in March/April, and then again from August to October (Feng 2007).

Overall, information on BMSB/YSSB management in kiwifruit orchards found in Chinese publications was limited. Most information refers to BMSB, but Feng (2007) implied that such management techniques would also be useful for YSSB. The options detailed were:

- Physical removal methods, including: (1) removal of overwintering sites (Mi et al. 2007); (2) removal of overwintering BMSB adults, including those found in purposefully constructed artificial overwintering shelters (Zhang et al. 2000; Feng 2007); (3) shaking or beating vines so that BMSB adults drop to the ground where they may be destroyed by burning in hay ground cover (Feng 2007) or with insecticides (Li et al. 2007); and (4) removal of BMSB egg masses and nymphs on the plants (Zhang et al. 2000). Removal (e.g. by beating) of the active stages of stink bugs may be most effective when they are inactive in the early morning or evening or in spring when temperatures are low (Feng 2007; Li et al. 2007; Mi et al. 2007; Zhang et al. 2013).

- Hanging a BMSB repellent (驱蝽王 'Quchunwang') from vines (Feng 2007).

- Chemical control including: (1) fogging/ fumigation for BMSB overwintering adults; (2) insecticide applications for nymphs as they hatch from the eggs; (3) smoke formulations with a sawdust/insecticide combination placed at the vine base; or (4) hanging insecticide containers in the vines (Zhang et al. 2000; Feng 2007; Zhang et al. 2013; Gao \& Yang 2017). Li et al. (2007) noted that some insecticide treatments were ineffective as BMSB re-infested orchards after treatment.

- Fruit bagging technology has failed to protect fruit (not just kiwifruit) from BMSB (Li et al. 2007).

- Using light traps were mentioned as a management tool by Zhang et al. (2013).

- Using biological control. A generalised mention of biological control was included in a range of techniques for managing pests and diseases (including stink bugs) in organic kiwifruit systems by Mi et al. (2007). More recently, specific mention has been made of biological control for BMSB by parasitoids in kiwifruit (Mi et al. 2017).

\section{DISCUSSION}

This study has two significant findings. Firstly, it provides the first comprehensive confirmation in English that BMSB and YSSB are major pests of kiwifruit in China and that, therefore, they represent significant biosecurity threats to New Zealand kiwifruit crops. Secondly, it reinforces the need to access information on pests and diseases found in China from databases that include Chinese language publications so that adequate risk assessments can be made. 


\section{Pest status}

Despite the very small number of references to BMSB and YSSB as pests of kiwifruit in English language publications, the number and variety of references in Chinese language publications over 20 years indicates that these two stink bugs are both major pests of kiwifruit in China and, therefore, of considerable biosecurity concern for New Zealand. Many of the Chinese publications were short observational accounts rather than robust experimental undertakings and, therefore, it would be prudent to initiate research to verify the extent of BMSB impact on kiwifruit under experimental conditions, and particularly under management regimes that may more suitably reflect New Zealand conditions. For example, differences in pesticide availability and use, the availability of biocontrol agents and different susceptibilities of various kiwifruit cultivars to BMSB, may have important influences on the degree of stink-bug impact on kiwifruit.

Since at least 2012, BMSB has been acknowledged to be a biosecurity threat to a wide variety of horticulture and cropping plants in New Zealand (Duthie 2012). Due to its polyphagous feeding habits and the high risk of BMSB entry and establishment in New Zealand (M Dyck pers. comm.), Kiwifruit Vine Health (KVH) (a New Zealand biosecurity organisation) placed BMSB on its most unwanted pest list in 2014 (KVH 2016). KVH's decision would now seem to be a very wise given subsequent occurrences of BMSB at New Zealand's borders and based on the information from China presented here. It may also be sensible for $\mathrm{KVH}$ to consider YSSB as an addition to this list or to treat stink bugs as a generic group for biosecurity threats. Recently, BMSB feeding damage to kiwifruit fruit has been confirmed in the laboratory (Lara et al. 2018) and there are recent anecdotal reports of BMSB damage to kiwifruit in Italy (Anon. 2017b). Kiwifruit Vine Health has joined a BMSB Operational Agreement as part of the Government Industry Agreement (GIA) for Biosecurity Readiness and Response to prevent the establishment of BMSB and/or to develop plans to mitigate its impact if it establishes in
New Zealand (GIA 2018).

\section{Chinese literature}

By far the greatest numbers of publications on the pest status of BMSB and YSSB on kiwifruit were found in Chinese language searches in the Chinese search platform (CNKI). The lowest number of publications were found with English character searches in international search platforms (Table 3). Both kiwifruit and BMSB/YSSB are native to China, so there is some expectation that there would be more publications on these pest/crop combinations there, compared with other major kiwifruit producing countries (Ferguson 2015) where BMSB has only recently established, such as Italy in 2012 (Maistrello et al. 2016) and Chile in 2017 (Faúndez \& Rider 2017). To date, BMSB has not established in New Zealand. Few (none in WoS and ProQuest and four in Google Scholar) Chinese language publications were found in international databases despite more than half $(9 / 16)$ of the publications including Latin scientific names or English abstracts. These publications were apparently not catalogued within the international databases; possibly because they were publications targeting technical rather than academic audiences. Nevertheless, the information within these publications that does not appear in international search platforms would appear to be critical for effective biosecurity risk assessment for BMSB on kiwifruit and other pest/crop combinations of biosecurity significance to New Zealand (Xu et al. 2016). Google Scholar searches an ill-defined set of literature found throughout the internet, whereas CNKI, WoS, and ProQuest comprise datasets consisting of a finite set of scientific publications or reports at any given point in time. Google Scholar is also sometimes blocked for use in China (Normile 2017), which may limit its utility and make any consistent searching of Chinese literature from this source less reliable than sources not blocked for use in China.

The findings obtained on YSSB are just as illustrative. While YSSB is recognised as a biosecurity risk to New Zealand (Anon. 2014), the little information published on the biosecurity 
status of YSSB here state: 'In their natural range in Asia there is little information recorded about their host range or impacts on plants and trees' (Anon. 2014). This statement may be true for English language publications but it is certainly not true for Chinese language publications as has been shown in this study.

As noted above, the Chinese language publications found by searching for BMSB and kiwifruit also provided lists and information on a wide range of other key pests and diseases of kiwifruit in China. Investigation of these additional species is warranted to assess their potential biosecurity significance for $\mathrm{New}$ Zealand kiwifruit.

Overall, the results from this study support the findings of Xu et al. (2016), that optimal and effective searching strategies for information on pest and disease species in China necessitate searching Chinese databases with Chinese characters in combination with the more usual searches in international databases, to ensure comprehensive coverage.

\section{ACKNOWLEDGEMENTS}

We thank colleagues Gonzalo Avila for reviewing translated publications and Megan Gee for support in searching the international information platforms. Matt Dyck (KVH), Cath McKenna (PFR) and Philippa Stevens (PFR) provided useful comments on an earlier draft. Kiwi Vine Health/Zespri funded the translations of the Chinese publications. Plant \& Food Research, through the Better Border Biosecurity (B3) research collaboration, funded the interpretation of the published data and the writing of this manuscript.

\section{REFERENCES}

Anon. 2014. Yellow spotted stink bug. Ministry for Primary Industries. Wellington, New Zealand. http://www.kvh.org.nz/vdb/ document/100435 (accessed March 2018).

Anon. 2015. Specialty Crops at Risk to BMSB

Damage. USDA. www.stopbmsb.org/whereisbmsb/crops-at-risk/ (accessed April 2018).

Anon. 2017a. Brown marmorated stink bug. https://www.mpi.govt.nz/protectionand-response/responding/alerts/brownmarmorated-stink-bug/ (accessed 18 March 2018).

Anon. 2017b. BMSB - kiwifruit impacts and on-orchard management. Kiwifruit Vine Health. http://www.kvh.org.nz/vdb/ document/103548 (accessed March 2018).

Cai L, Dong M, Du X 2008. The occurrence rule of brown marmorated stink bug Halyomorpha halys and its control strategies in the suburb of Beijing. Northern Horticulture 11: 166168. In Chinese.

Cui X, Li N, Li X, Hu Q, Bu W 2017. Recognition of late instars of nymphs among nine stinkbug species injuring crops and trees. Plant Protection 1(43): 83-88. In Chinese.

Du C, Fu Z, Zhao H 2011. Structure and dynamics of arthropod communities in kiwifruit orchards. Journal of Northwest A \& F University (Nat. Sci. Ed.) 39(11): 89-96. In Chinese.

Duthie C 2012. Risk analysis of Halyomorpha halys (brown marmorated stink bug) on all pathways. Ministry for Primary Industries. Wellington.

Faúndez EI, Rider DA 2017. The brown marmorated stink bug Halyomorpha halys (Stål, 1855) (Heteroptera: Pentatomidae) in Chile. Arquivos Entomolóxicos 17: 305-307.

Feng, $\mathrm{H}$ 2007. The occurrence and control of pests in kiwifruit orchards. Northwest Horticulture 12: 22. In Chinese.

Ferguson AR 2015. Kiwifruit in the world 2014. Acta Horticulturae 1096: 33-46.

Freshfacts 2017. Fresh facts. New Zealand Horticulture. The New Zealand Institute for Plant and Food Research. http://www. freshfacts.co.nz/ (accessed March 2018).

Gao N, Yang F 2017. The calendar of managing major kiwifruit diseases and pests. Northwest Horticulture 1: 32. In Chinese.

Ge Z 2012. The standards and management of young kiwifruit trees in the Shanghai region. Shanghai Agricultural Science and Technology 1: 61-63. In Chinese.

GIA 2018. Brown Marmorated Stink Bug 
(BMSB) Operational Agreement (OA). Government Industry Agreement for Biosecurity Readiness and Response. http:// www.gia.org.nz/Activities/BMSB-Council (accessed March 2018).

Guo X, Shi X 2003. The biology and integrated management of important kiwifruit pests in Shaanxi province. China Fruits 1: 45-46. In Chinese.

Haye T, Gariepy T, Hoelmer K, Rossi J-P, Streito J-C, Tassus X, Nicolas Desneux N 2015. Range expansion of the invasive brown marmorated stinkbug, Halyomorpha halys: an increasing threat to field, fruit and vegetable crops worldwide. Journal of Pest Science DOI 10.1007/s10340-015-0670-2.

Huang H, Ferguson AR 2001. Kiwifruit in China. New Zealand Journal of Crop and Horticultural Science 29(1): 1-14.

Kiwifruit Vine Health 2016. Most unwanted. http://www.kvh.org.nz/vdb/document/99225 (accessed March 2018).

Lara JR, Kamiyama M, Hernandez G, Lewis M, Hoddle MS 2018. Laboratory assessment of feeding injury and preference of brown marmorated stink bug, Halyomorpha halys Stål (Hemiptera: Pentatomidae), for Actinidia chinensis var. deliciosa 'Hayward' (Zespri ${ }^{\oplus}$ Green) and Actinidia chinensis var. chinensis 'Zesy002' (Zespri ${ }^{\circledR}$ SunGold). New Zealand Entomologist https://doi.org/10.1080/00779 962.2018.1438758.

Lee D-H, Short BD, Joseph SV, Bergh JC, Leskey TC 2013. Review of the biology, ecology, and management of Halyomorpha halys (Hemiptera: Pentatomidae) in China, Japan, and the Republic of Korea. Environmental Entomology 42:627-41.

Leskey TC, Nielsen AL 2018. Impact of the invasive brown marmorated stink bug in North America and Europe: history, biology, ecology, and management. Annual Review of Entomology 63: 599-618.

Li X, Yin X, Ma L, Liu Y, Fu J, Liu X 2007. Halyomorpha halys behaviour and their application for control. Journal of Northwest Agricultural \& Forestry University (Natural
Science Edition) 35(10): 139-145. In Chinese. MacFarlane RP, Maddison PA, Andrew IG, Berry JA, Johns PM, Hoare RJB, Lariviere M-C, Greenslade P, Henderson RC, Smithers CN, Palma RL, Ward JB, Pilgrim RLC, Leschen RAB, Towns DR, McLellan I, Teulon DAJ, Lawrence JF, Kuschel G, Wang Q, Hitchings TR, Eastop VF, Martin NA, Fletcher MJ, Stufkens MAW, Dale PJ, Burckhardt D 2010. Phylum Arthropoda. Subphylum Hexapoda. Protura, springtails, diplura, and insects (Chapter 9). In: Gordon, DP ed. New Zealand Inventory of Biodiversity Volume 2. Kingdom Animalia. Chaetognatha, Ecdysozoa, Ichnofossils. Canterbury University Press, Christchurch, New Zealand. Pp. 233-467.

Maistrello L, Dioli P, Bariselli M, Mazzoli GL, Giacalone-Forini I 2016. Citizen science and early detection of invasive species: phenology of first occurrences of Halyomorpha halys in southern Europe. Biological Invasions 18: 3109-3116.

Mi H, Zhang H, Liu B 2007. Main technologies of pest management on Shaanxi organic kiwifruit production. Academic Periodical of Farm Products Processing 94(3): 85-87. In Chinese.

Mi QQ, Zhang JP, Han YX, Yan YC, Zhang BX, Li DS, Zhang F 2017. Releases of Trissolcus japonicus and Anastatus sp. for suppression of Halyomorpha halys in kiwifruit orchards. Proceedings of the 5th International Symposium on Biological Control of Arthropods, Langkawi, Malaysia, September 11-15, 2017. doi:10.1079/9781786394118.0297. Abstract only.

Normile D 2017. Science suffers as China's internet censors plug holes in Great Firewall. http://www.sciencemag.org/news/2017/08/ science-suffers-china-s-internet-censorsplug-holes-great-firewall (accessed March 2018).

Rice KB, Bergh CJ, Bergmann EJ, Biddinger DJ, Dieckhoff C, Dively G, Fraser H, Gariepy T, Hamilton G, Haye T, Herbert A, Hoelmer K, Hooks CR, Jones A, Krawczyk G, Kuhar 
T, Martinson H, Mitchell W, Nielsen AL, Pfeiffer DG, Raupp MJ, Rodriguez-Saona C, Shearer P, Shrewsbury P, Venugopal PD, Whalen J, Wiman NG, Leskey TC, Tooker JF 2014. Biology, ecology, and management of brown marmorated stink bug (Hemiptera: Pentatomidae). Journal of Integrated Pest Management 5: A1-13.

Rider DA, Zheng LY, Kerzhner IM 2002. Checklist and nomenclatural notes on the Chinese Pentatomidae (Heteroptera). II. Pentatominae. Zoosystematica Rossica 11: 135-153.

Song X, Zheng W, Zhang X, Ma S 1997. Investigation of kiwifruit pests and diseases in Shaanxi Province. Forest Pest and Disease 4: 17-19. In Chinese.

Song X, Wang P, Zhang X, Ma S, Li Y 1998. Investigation and analysis on occurrence and damage of diseases and pests on kiwifruit in the Shaanxi province. Journal of Northwest Forestry College 13(3): 79-84. In Chinese.

Statistics New Zealand 2017. Global New Zealand - International trade, investment, and travel profile: year ended December 2014. http://www.stats.govt.nz/browse_for_stats/ industry_sectors/imports_and_exports/ global-nz-dec-16/key-points.aspx. (Accessed March 2018).

Sun T 2017. 猕猴桃 and 奇异果. Food and Health 6: 18.

Teulon DAJ, Xu B 2017. Chinese language publications are important for understanding the likely impact of brown marmorated stink bug to kiwifruit. New Zealand Plant Protection 70: 316. Abstract only.

Tourism New Zealand 2018. Markets and Stats. https://www.tourismnewzealand.com/ markets-stats/ (accessed March 2018).

Vanneste JL 2017. The scientific, economic, and social impacts of the New Zealand outbreak of bacterial canker of kiwifruit (Pseudomonas syringae pv. actinidiae). Annual Review of Phytopathology 55: 377-399. doi: 10.1146/ annurev-phyto-080516-035530.

$\mathrm{Xu}$ B, Shaw N, Gee M, Teulon DAJ 2016. A quantitative comparison of articles on two pests and two pathogens of biosecurity risk to New Zealand extracted from international and Chinese databases. New Zealand Plant Protection 69: 176-185.

Yang Q, Xie Z, Wang L, Yang X, Hu N 2014. The biology of kiwifruit pests and OPM techniques in organic orchards of Hubei province. Southern Fruit Trees 43(6): 132134. In Chinese.

Yang Z-Q, Yao Y-X, Qiu L-F, Li Z-X 2009. A new species of Trissolcus (Hymenoptera: Scelionidae) parasitizing eggs of Halyomorpha halys (Heteroptera: Pentatomidae) in China with comments on its biology. Annals of Entomological Society of America 102: 3947. doi:10.1603/008.102.0104

Zhao Y, Qu X 2008. The control of pests and diseases during the kiwifruit dormant period. Fruit Growers' Friend 12: 31-32. In Chinese.

Zhang F, Chen Z, Zhang S 2000. The occurrence and control of Halyomorpha halys in kiwifruit orchards. Northwest Horticulture 2: 38. In Chinese.

Zhang Y, Xu J, Jia H, Feng H, Li G 2013. The integrated control of kiwifruit diseases and pests. Fruit Growers' Friend 10: 26. In Chinese.

Zhang Y, Feng H, Xu J, Han Y, Li G, Du Y 2014. Investigation of kiwifruit diseases and pests in Xian and their characteristics. Fruit Growers' Friend 5: 33-34. In Chinese. 